\title{
Grafite com arte: o trabalho do grupo Sprays Poéticos como uma representação de arte de rua na cidade de São Paulo
}

\section{Jordana Falcão}

TAVARES

\section{Resumo}

A contemporaneidade é permeada de desencaixes e descontinuidades. Nela, compondo o cenário visual dos meios urbanos, o grafite se destaca como manifestação visual. Sendo um signo desse cenário e da própria contemporaneidade, nos termos propostos para essa pesquisa. O grafite, enquanto gênero híbrido, questiona as representações visuais sedimentadas sobre a própria paisagem urbana e sobre as linguagens artísticas. Nesse sentido, elegi o grafite como tema da minha pesquisa para a dissertação de mestrado, tendo como objetivo compreendê-lo enquanto manifestação de arte de rua, abordá-lo como ponto de convergência para a criação e resistência de identidades, como espaço para as identificações de várias subjetividades. Para isso defini como lócus da pesquisa a cidade de São Paulo, e como objeto específico o trabalho do Grupo Sprays Poéticos, que é composto por grafiteiros e poetas. A partir das ações propostas por esse grupo, vou tratar de conceitos e noções como contemporaneidade, desencaixes e descontinuidades, hibridismo, identidade, identificações e visualidades urbanas.

Palavras-chave: Grafite, visualidade urbana, Sprays Poéticos. 